\title{
COMPARING ECOLOGICAL RISKS OF PESTICIDES ON UNICELLULAR FRESHWATER GREEN ALGA; Pseudokirchneriella subcapitata Using A Risk Quotient RANKING APPROACH.
}

Abd-Allah, Salwa M. ${ }^{1}$ and Neama A. Gouda ${ }^{2}$

(1) Mammalian and Aquatic Toxicity Dept., Central Lab of Agricultural Pesticides, Agricultural Research Center, Alexandria, Egypt. ${ }^{(2)}$ Pesticide Chemistry and Toxicology Dept., Faculty of Desert and Environmental Agriculture (Fuka; Marsa Matrouh), Alexandria University, Egypt.

\begin{abstract}
Environmental risk assessment of pesticides often uses the Risk Quotient (RQ) method to characterize risk quantitatively. Toxicological effects of pesticides (for 5 fungicides, 4 herbicides and 6 insecticides formulations) were assessed on the green alga Pseudokirchneriella subcapitata. For each tested pesticide, 96-h acute toxicity test was conducted and toxicity end-points and $R Q$ values based on refinement of exposure concentrations were evaluated. Risk presumptions were presented along with the corresponding level of concern (LOC). Toxicity data indicated differential numerical ranking of pesticides within each pesticide category. For fungicides; mancozeb was found to be the most toxic and difenoconazole was the least toxic (3006 and 93 fold of toxicity; respectively). As related to herbicides, metribuzin was the most effective (1349 fold of toxicity), while cryomazine was practically non-toxic. Moreover, abamectin proved to be the extremely toxic insecticide (5511 fold of toxicity). Numerical ranking of toxicity was significantly correlated with the $R Q$ ranking in most cases and depends on the nature of the pesticide, bioavailability and exposure concentrations. Associated risk presumptions proved that abamectin, lambda-cyhalothrin, chlorfluazuron and mancozeb pose the worst case acute risk to non-target organisms in aquatic ecosystem and consequently a regulatory action may be warranted in addition to restricted use classification $(\mathrm{RQs}=27.769 ; 21.568 ; 14.833$ and 11.678 ; respectively exceeding LOC). Based on $\mathrm{RQ}$ values, risk presumption due to exposure of $P$. subcapitata to all tested insecticides represents the highly acute potential risk $(R Q=2.988-27.769$ exceeding LOC). Fungicides are also presumed to pose a high risk on aquatic ecosystem but in a trend lower than insecticides. Among tested herbicides, only metribuzin and thiobencarb are presumed to pose a high acute risk on aquatic ecosystem $(R Q=2.306$ and 1.167; respectively exceeding LOC). The results support the hypothesis that numerical ranking of $R Q$ s can be used for the purpose of comparing potential ecological risks and such data may add to the pesticide existing database concerning the potential adverse effects of pesticides on aquatic ecosystem.

Keywords: Pesticide toxicity, comparative risk assessment, risk ranking, green algae *Corresponding author: Sabdallah@link.net
\end{abstract}

\section{INTRODUCTION}

Areas with intensive agriculture are generally highly integrated with aquatic ecosystems because of their dependence on water supply and/or drainage. These aquatic systems not only support agricultural needs but also function as an important habitat for many water organisms. With the actual application techniques of pesticides used for crop protection, however, it is 
inevitable that part of the sprayed amount will enter these non-target surface waters (Capri and Trevistan, 1998). As a result, bodies of water may be contaminated with a mixture of insecticides, fungicides, and herbicides. Several studies have documented that pesticide residues occur in aquatic ecosystems in agricultural areas, often with several pesticides co-occurring (Hoysaeter, 1994; Larson et al., 1999).

Aquatic ecosystems contain many species and undesirable sideeffects are to be expected when these systems become contaminated. Algae are important components of the primary production in aquatic ecosystem and detrimental effects in these organisms may affect the entire food chain. Pseudokirchneriella subcapitata (formerly Selenastrum capricornutum) is a unicellular chlorophyceae algae that was widely used in studies of pollutants effects (Jonsson et al., 1998; Okamura et al., 2002) and recommended by regulatory national (CETESB, 1992; Jonsson and Maia, 1999) and international (OECD, 1984; USEPA, 1994) agencies as a test organism.

Environmental risk assessment of pesticides and other chemicals often uses the Risk Quotient (RQ) method to characterize risk quantitatively. For each ecological receptor, a $R Q$ is a ratio of exposure to effect and calculated by dividing the estimated or actual environmental concentration by the appropriate toxicity end-point. The $R Q$ can be used by risk analysts and decision makers to assess whether the value exceeds any predetermined threshold levels of concern (LOC) for the purpose of making comparisons of environmental risk among pesticides (Maud et al., 2001; Peterson and Hulting, 2004) and identify the need for considering a regulatory action. Consequently, the ecological relevance of estimated risk quotient is one of the main items in recent ecotoxicological research with pesticides (Leeuwangh et al., 1994; Maund et al., 1997).

The aim of this study was to assess quantitatively the potential hazards of pesticides to the freshwater organism $P$. subcapitata through measuring toxicity end-point and estimating RQs in relationship with Level of Concern (LOC).

\section{MATERIALS AND METHODS}

Chemicals: Tested pesticides were obtained from the Central Lab of pesticides; Agricultural Research Center, Ministry of Agriculture, Egypt. Their chemical names are shown in Table (1).

\section{Test organism and culture conditions}

The green alga Pseudokirchneriella subcapitata obtained from Faculty of Science; Mansoura University, Egypt; was used as a test organism. The stock culture was maintained according to USEPA (2002) and OECD (2002) in $250 \mathrm{ml}$ borosilicate Erlenmeyer flasks containing culture medium at $24 \pm 2^{\circ} \mathrm{C}$, under a continuous white fluorescent light of $3000-4000$ lux and manually shake twice a day. 
J. Plant Prot. and Path., Mansoura Univ., Vol. 3 (9), September, 2012 
Abd-Allah, Salwa M. et al.

Axenic culture was maintained in standard AAM nutrient media as described in Miller et al. (1978). Two $\mathrm{ml}$ of stock culture were weekly transferred into $100 \mathrm{ml}$ of new culture medium to maintain a continuous supply of "healthy" cells for the tests.

\section{Acute toxicity test}

Algal acute toxicity test was conducted using different concentrations of a pesticide in sterile algal AAM growth media. Tested concentrations of a pesticide were prepared from stock solutions on an arithmetic progression covering an expected range of toxicity from 0 to $90 \%$. The final volume of AAM medium containing tested chemical was $50 \mathrm{ml}$. An inoculum of exponentially-growing culture of $P$. subcapitata (harvested from 4-7 days stock culture) was prepared no more than $2-3 \mathrm{hr}$ prior to beginning of the test. Initial cell density for the growth inhibition test was $10,000 \mathrm{cells} / \mathrm{ml}$. Controls containing only growth medium and algae were included. The test vessels were incubated continuously in a temperature-controlled $\left(25^{\circ} \mathrm{C}\right)$ orbital shaker set at $100 \mathrm{rpm}$ under continuous illumination provided by white fluorescent lamps. Zero-time begins when we inoculate the test flasks containing the media and the tested pesticide with the algal cells followed by incubation for $96 \mathrm{hr}$. At the end of $96 \mathrm{hr}$, the growth of the alga in terms of viable cell concentration was determined in a Neubaur hemocytometer using a phase contrast microscope (Megharaj et al., 1999) accompanied with measurement of change in $\mathrm{pH}$. Growth inhibition (biomass) of the alga was used as the end point in this bioassay. All assays were conducted in duplicate. The percent inhibition values calculated relative to growth in untreated controls were used to obtain the inhibitive concentration; $E_{50}$ (concentration inhibitory to $50 \%$ of growth).

\section{Estimation of risk quotient}

In the deterministic approach, according to the Office of Pesticide Programs (OPP), Environmental Fate and Effects Division (EFED- EPA, 2009), a risk quotient (RQ) is a simple screening-level estimate calculated by dividing a point estimate of exposure by a point estimate of effects.

Risk quotient $(R Q)=$ Exposure/ Toxicity

For each pesticide type (herbicide, fungicide and insecticide) and aquatic risk type, toxicities and RQs based on refinements of estimated and actual environmental exposures were ranked numerically from highest toxicity or $\mathrm{RQ}$ to lowest. After the risk quotient(s) was calculated, it is compared to the Agency's Level of Concern (LOC). An LOC is a policy tool that the Agency uses to interpret the risk quotient and to analyze potential risk to nontarget organisms and the need to consider regulatory action.

\section{Statistical analysis}

The growth rates were calculated according to official guidelines (OECD, 2002). Percent of inhibition in algal growth (\%l) relative to growth in control systems were calculated and $\mathrm{EC}_{50}$ (median or half maximum effective concentration) values and other statistical parameters were estimated using Probit analysis (Finney, 1971). 


\section{RESULTS}

Toxicity endpoints values after exposure of $P$. subcapitata to 15 pesticides ( 5 fungicides, 4 herbicides and 6 insecticides) were illustrated in Table (2). The sensitivity; expressed as $\mathrm{EC}_{50}$, ranged from $0.024-132.256$ $\mathrm{mg} / \mathrm{L}$. The $\mathrm{EC}_{50}$ values of fungicides; mancozeb, copper hydroxide, copper sulfate anhydrous, probiconazole, flusilazole and difenoconazole were 0.044 , $0.093,0.371,0.578,1.070$ and $1.419 \mathrm{mg} / \mathrm{L}$; respectively. Toxicity of herbicides including metribuzin, thiobencarb, glyphosate and cryomazine showed different patterns of $\mathrm{EC}_{50} \mathrm{~S}(0.098,9.903 \mathrm{E}-2,18.220$ and 132.256 $\mathrm{mg} / \mathrm{L}$; respectively), while those of insecticides; abamectin, chlorfluazuron, lambda cyhalothrin, amamectin benzoate and cypermethrin were 0.024 , $0.035,0.068,0.107$ and $2.535 \mathrm{mg} / \mathrm{L}$; respectively. Based on $\mathrm{EC}_{50}$ values, $P$. subcapitata was more sensitive to the insecticide; abamectin and less sensitive to herbicide; cryomazine. The decreasing order of the sensitivity to green alga, in general, was as follows: abamectin> chlorfluazuron> mancozeb> lambda cyhalothrin> copper hydroxide > metribuzin > thiobencarb> amamectin benzoate> copper sulfate anhydrous $>$ probiconazol> flusilazole $>$ difenoconazole $>$ cypermethrin $>$ glyphosate $>$ cryomazine.

Table (2): Differential Sensitivity of $P$. subcapitata to different pesticides.

\begin{tabular}{|c|c|c|c|c|c|}
\hline Pesticide & $\begin{array}{c}\mathrm{EC}_{50} \\
(\mathrm{mg} / \mathrm{L})\end{array}$ & $\mathrm{CL}^{\mathrm{a}}$ & $\mathrm{VL}^{\mathrm{b}}$ & $\mathbf{S}^{c}$ & $\begin{array}{l}\text { Regression } \\
\text { equation }\end{array}$ \\
\hline $\begin{array}{l}\text { Fungicides } \\
\text { Copper hydroxide }\end{array}$ & 0.093 & $(0.082-0.105)$ & $3.300 \mathrm{E}-1$ & 4.427 & $Y=4.567+4.427 X$ \\
\hline Copper sulfate & .371 & $(0.262-0.538)$ & $1.583 \mathrm{E}-2$ & 1.124 & $Y=0.483+1.124 X$ \\
\hline \begin{tabular}{|l} 
Difenoconazole \\
\end{tabular} & 1.419 & $(1.269-1.593)$ & $2.144 \mathrm{E}-2$ & 1.876 & $Y=1.876 X-0.285$ \\
\hline Flusila & $1.0 / 0$ & $(0.909-1.287)$ & 4.13 & 1.634 & \\
\hline Mancozeb & 0.044 & $(0.029-0.066)$ & $1.394 \mathrm{E}-3$ & 0.516 & $Y=0.699+0.516 X$ \\
\hline Probiconazole & 0.578 & \begin{tabular}{|l}
$(0.387-0.902)$ \\
\end{tabular} & $7.297 \mathrm{E}-3$ & 0.896 & $.896 \mathrm{X}$ \\
\hline $\begin{array}{l}\text { Herbicides: } \\
\text { Cryomazine }\end{array}$ & 132.256 & $\begin{array}{l}(118.579- \\
147.558)\end{array}$ & $5.541 \mathrm{E}-2$ & 2.513 & 5.332 \\
\hline Glyph & 18.220 & $\begin{array}{l}(10.124- \\
38.392)\end{array}$ & $1.660 \mathrm{E}-3$ & 0.477 & 601 \\
\hline Metrib & 98 & $(0.083-0.117)$ & $2.147 \mathrm{E}-2$ & 1.629 & .641 \\
\hline Thiobenca & 0.099 & $(0.075-0.131)$ & $8.518 \mathrm{E}-3$ & 0.991 & $991 \mathrm{X}$ \\
\hline $\begin{array}{l}\text { Insecticides: } \\
\text { Abamectin }\end{array}$ & 0.024 & $(0.015-0.036)$ & $2.256 \mathrm{E}-3$ & 0.596 & $Y=0.970$ \\
\hline Amamectin be & 107 & $(0.08$ & $2.447 \mathrm{E}-3$ & 0.987 & $.987 X$ \\
\hline Chlorfl & & $(0.029$ & $9.963 \mathrm{E}-3$ & 1.463 & $\mathrm{Y}=2$ \\
\hline lambda Cyhalo & 0.068 & $(0.043-0.111)$ & $8.138 \mathrm{E}-4$ & 0.432 & $Y=0.432 X+0.794$ \\
\hline Cypermethrin & 2.535 & $(1.975-3.306)$ & $7.780 \mathrm{E}-3$ & 1.024 & $Y=1.024 X-0.414$ \\
\hline
\end{tabular}

$\mathrm{CL}^{\mathrm{a}}: \mathbf{9 5 \%}$ Confidence Limits, $\mathrm{VL}^{\mathrm{b}}$ : Variance of slope, $\mathrm{S}^{\mathrm{c}}$ : Slope. 
Abd-Allah, Salwa M. et al.

For each pesticide type (fungicide, herbicide and insecticide), toxicities and the RQs based on refinements of estimated and actual media exposures were ranked numerically from lowest toxicity or $R Q$ to highest. Table 3 shows ranking of the tested pesticides based on their fold of toxicity and their estimated risk quotients. The results showed that, abamectin and chlorfluazuron were highly toxic (5510.66 and 3778.74 fold of toxicity; respectively) compared with cryomazine which was considered practically non-toxic to the tested alga.

Furthermore, data indicated that numerical ranking of toxicity was significantly correlated with the $R Q$ ranking in most cases depending on the nature of the compound, bioavailability and concentrations of exposure. $R Q$ values ranged from 0.591 to 27.769 . Abamectin was the most toxic one and cryomazine was the lowest ( $R Q$ values were 27.769 and 0.832 ; respectively). Comparison of estimated $R Q$ values with $L O C$ for interpretation and analyzing potential risk to non-target organisms ffor nonvascular plants (green algae or diatoms) and for short-term acute toxicity value less than 10 days, the LOC value is 1$\}$, data disclosed that risk presumption is acute high risk when RQ, LOC equal 1.0 or exceed (as noticed for the effects of cypermethrin, flusilazole, probiconazole, copper sulfate, amamectin benzoate, thiobencarb and metribuzin). Additionally, an extremely high acute risk presumption (worst case risk) on aquatic organisms is suggested upon exposure to mancozeb, chlorfluazuron, lambda cyhalothrin and abamectin since RQs recorded 11.68, 14.83, 21.57 and 27.77; respectively). When LOC equal less than 1.0 (as noticed for cryomazine, glyphosate and copper hydroxide), risk presumption is acute endangered species.

Table (3): Toxicity rating and estimated risk quotient of the tested pesticides on P.subcapitata.

\begin{tabular}{|c|c|c|}
\hline Pesticide & Fold of toxicity ${ }^{*}$ & $\mathbf{R Q}$ \\
\hline Cryomazine & Practically non-toxic & 0.832 \\
\hline Glyphosate & 7.23 & 0.835 \\
\hline Cypermethrin & 52.17 & 2.988 \\
\hline Difenoconazole & 93.20 & 0.982 \\
\hline Flusilazole & 123.60 & 1.918 \\
\hline Probiconazol & 228.82 & 1.153 \\
\hline Copper sulfate & 356.48 & 1.582 \\
\hline Amamectin benzoate & 1236.04 & 5.684 \\
\hline Thiobencarb & 1335.51 & 1.167 \\
\hline Metribuzin & 1349.55 & 2.306 \\
\hline Copper hydroxide & 1422.13 & 0.591 \\
\hline lambda Cyhalothrin & 1944.92 & 21.568 \\
\hline Mancozeb & 3005.82 & 11.678 \\
\hline Chlorfluazuron & 3778.74 & 14.833 \\
\hline Abamectin & 5510.66 & 27.769 \\
\hline
\end{tabular}

${ }^{\star}$ Fold of toxicity is referred to the lowest toxicity value of cryomazine.

\section{DISCUSSION}

Our current study points out possible risk presumptions due to exposure to different pesticide categories and the risk was expressed quantitatively as estimated $R Q$ values. Our results strongly confirm the 
potential risk of pesticides on aquatic ecosystem. Lethal and effective concentrations tested in this study disclosed that even short exposures of freshwater ecosystem to pesticides concentrations in the $\mu \mathrm{g}$-range might result in acute effects on unicellular chlorophyceae algae; $P$. subcapitata and might lead to a decrease of its populations. There are few literatures describing the ecological risk effects of pesticides on freshwater algae and comparative documents are rarely available.

Numerical ranking of toxicity was significantly correlated with the $R Q$ ranking in most cases depending on the nature of the compound, bioavailability and concentrations of exposure. Based on $R Q$ values (Table 3 ), risk presumption due to exposure of $P$. subcapitata to all tested insecticides represents the worst acute risk case $(R Q=2.988-27.769$ exceeding LOC) and hence a regulatory action may be warranted in addition to restricted use classification. The order of risk ranking based on estimated RQs is abamectin> lambda cyhalothrin> chlorfluazuron> amamectin benzoate> cypermethrin. The high toxicity observed in exposure to abamectin (as indicated in $\mathrm{EC}_{50}$ and $\mathrm{RQ}$ values) corroborates with the findings of Tisler and Erzen (2006). Furthermore, risk presumption due to amamectin benzoate exposure on $P$. subcapitata (Table 3 ) proved to be acute high risk $(R Q=5.684)$ when compared with $L O C$ and such result agree with the findings of Garric et al., 2007. The ecological risk caused by abamectin is presumed to be more serious than by amamectin benzoate (Table 3). Although abamectin is not directly used in aquatic ecosystems, it may have adverse effects on aquatic biota either phytoplankton (Wislocki et al., 1989; Vieira, 2010) or zooplankton (Novelli, 2010) through direct application as well as via runoff from experimentally contaminated plots. Additionally, ivermectin compounds showed worst case risk presumptions $(R Q=1.05-36.2)$ and many efforts were made to prevent repeated entry in aquatic environments and thus its accumulation in sediments (Garric et al., 2007).

Fungicides were also presumed to pose a high acute risk on aquatic ecosystem but in a trend lower than insecticides and this may be mitigated through restricted use classification. Four compounds out of six tested fungicides recorded $R Q$ values exceeding LOC. The order of risk ranking based on estimated RQs is mancozeb> flusilazole> copper sulfate> probiconazole> difenoconazole> copper hydroxide. Both mancozeb and flusilazole are presumed to pose a high acute risk on aquatic ecosystem $(R Q=11.678$ and 1.918; respectively exceeding $L O C)$ and such findings are strengthened by USEPA where both compounds were considered as algistatic, rather than algicidal on $P$. subcapitata based on the respective studies (USEPA, 2005). Furthermore, it's worthy to mention that although the toxicity of copper hydroxide is higher than toxicity of copper sulfate $(\approx 3$ times fold), but estimated $R Q$ values of copper sulfate were higher than for copper hydroxide. Comparative studies; regarding only $\mathrm{EC}_{50}$ toxicity value, reported the toxic effect of copper sulphate (Gregor et al., 2008) and copper oxide 
nano particles (Aruoja et al., 2009) on $P$. subcapitata. The toxicity of copper oxides was due to the solubilized bioavailable fraction, most likely $\mathrm{Cu}^{2+}$ ions. The bioavailable $\mathrm{EC}_{50}$ values of copper oxides $(0.71 \mathrm{mg} / \mathrm{L})$ were significantly different from the $\mathrm{EC}_{50}$ of copper sulphate $(0.02 \mathrm{mg} / \mathrm{L})$.

Among tested herbicides, only metribuzin and thiobencarb are presumed to pose a high acute risk on aquatic ecosystem $(\mathrm{RQ}=2.306$ and 1.167; respectively exceeding LOC). The order of risk ranking based on estimated RQs is metribuzin > thiobencarb> glyphosate> cryomazine. Our data are consistent with other studies where both thiobencarb and metribuzin were toxic to $P$. subcapitata with a $120-\mathrm{hr} \mathrm{EC}_{50}$ of $17 \mu \mathrm{g} / \mathrm{L}$ and $0.043 \mu \mathrm{g} / \mathrm{mL}$; respectively (EFED-EPA, 2009; Choi et al., 2012). In other situation, both acute exposure and $R Q$ were estimated for metribuzin $(20.815 \mathrm{ppb}$ and 5.215; respectively) whereas, these estimates recorded $17 \mathrm{ppb}$ and 5.8553; respectively for thiobencarb (Peterson, 2006). On the other hand, when LOC equal less than 1.0 (as noticed for glyphosate) risk presumption is acute endangered species and a regulatory action may be warranted. Comparatively, acute toxicity of formulated products containing glyphosate tested on freshwater $P$. subcapitata indicated that glyphosate is generally less toxic to aquatic vascular plants than to algae $\left(E C_{50}=12.5\right.$ ppm)(Patterson, 2004).

\section{CONCLUSION}

The results reported herein support the hypothesis that numerical ranking of RQs for the purpose of comparing potential ecological risks of pesticides is a valid approach. Ranking based only on toxicity was statistically correlated with the $R Q$ estimates except in few cases. Therefore, ranking of ecological risk based solely on toxicity should not be used or should be used with caution. Ranking among pesticides based on RQs, especially for acute risks, should largely be used and interpreted based on refined environmental exposure estimates and actual values. Accordingly, the use of pesticides to control pests should be accompanied by efforts to limit, as far as possible, the contamination of aquatic ecosystems.

\section{REFERENCES}

Aruoja, V.; Dubourguier, H.C.; Kasemets, K. and Kahru, A. (2009). Toxicity of nanoparticles of $\mathrm{CuO}, \mathrm{ZnO}$ and $\mathrm{TiO} 2$ to microalgae; Pseudokirchneriella subcapitata. Sci.Total Environ., 407: 14611468.

Capri, E. and Trevisan, M. (1998). Prediction of environmental concentrations (PECs) by mathematical model applications in Europe. Pest. Outlook, 9: 26-30.

CETESB (1992). Procedimentos para a Utilizac,ão de Testes de Toxicidade no ontrole de Efluentes Li'quidos. Se'rie Manuais, CETESB, São Paulo. 
Choi, C.J.; Berges, J.A. and Young, E.B. (2012). Rapid effects of diverse toxic water pollutants on chlorophyll a fluorescence: Variable responses among freshwater microalgae. Water Res., 46: 26152626.

EFED- EPA (2009). Potential Risks of Thiobencarb Use to Federally Threatened California Red-legged Frog (Rana aurora draytonii) and Delta Smelt (Hypomesus transpacificus). Environmental Fate and Effects Division, Office of Pesticide Programs, Washington, D.C. 20460

Finney, D.J. (1971). Probit Analysis. Third Edition. Cambridge Press, New York, NY. pp. 668.

Garric, J.; Vollat, B.; Duis, K.; Pery, A.; Junker, T.; Ramil, M.; Fink, G. and Ternes, T.A. (2007). Effects of the parasiticide ivermectin on the cladoceran Daphnia magna and the green alga Pseudokirchneriella subcapitata. Chemosphere, 69: 903-910.

Gregor, J.; Jancula, D. and Marsalek, B. (2008). Growth assays with mixed cultures of cyanobacteria and algae assessed by in vivo fluorescence: One step closer to real ecosystems?. Chemosphere, 70: 1873-1878.

Hoysaeter, T. (1994). Pesticides in surface water and in sediments in Norway. In: Helweg, A. (Ed.), Pesticides in Precipitation and Surface Water, TemaNord 1995:558. Nordic Council of Ministers, Copenhagen, pp. 103-118.

Jonsson, C.M. and Maia, A.H.N. (1999). Protocolo de Avaliac,a a de Agentes Microbianos de Controle Biolo'́gico de Pragas para Registro como Biopesticidas. III. Testes em Organismos Não Alvo do Ambiente Aqua'tico. Se'rie Documentos. Embrapa Meio Ambiente, Jaguariu'na.33p.

Jonsson, C.M.; Maia, A.H.N.; Ferreira, C.J.A. and Ribeiro, E.O. (1998). Risk assessment of the herbicide clomazone to aquatic life. Verh. Int. Verein. Limnol., 26: 1724-1726.

Larson, S.J.; Gilliom, R.J. and Capel, P.D. (1999). Pesticides in streams of the United States-Initial results from the national water-quality assessment program. US Geological Survey, Water-Resource Investigation Report 98-4222.

Leeuwangh, P.; Brock, T.C.M. and Kersting, K. (1994). An evaluation of four types of freshwater model ecosystem for assessing the hazard of pesticides. Hum. Exp. Toxicol., 13: 888-899.

Maud, J.; Edwards-Jones, G. and Quin, F. (2001). Comparative evaluation of pesticide risk indices for policy development and assessment in the United Kingdom. Agric. Ecosyst. Environ., 86:59-73.

Maund, S.J.; Sherratt, T.N.; Strickland, T.; Biggs, J.; Williams, P.; Shillabeer, N. and Jepson, P.C. (1997). Ecological considerations in pesticide risk assessment for aquatic ecosystems. Pest. Sci., 49: 185-190. 
Megharaj, M.; Singlenton, I.; Kookana, R. and Naidu, R. (1999). Persistence and effects of fenamiphos on native algal populations and enzymatic activities in soil. Soil Biol. Biochem., 31:1549-53.

Miller, W.E.; Greene, J.C. and Shiroyama, T. (1978). The selenastrum capricornutumn algal assay bottle: Experimental design, application and data interpretation protocol. EPA-600/9-78-018, U.S.EPA, Corvallis, OR.

Novelli, A. (2010). Efeito do Vertimec_18CE e de seu principio ativo, a abamectina,

em ambiente aquatico: uma analise laboratorial e in situ. Doctoral thesis. Escola

de Engenharia de Sao Carlos, Universidade de Sao Paulo, Sao Carlos, SP, Brazil.

OECD (1984). Test Guideline 201 (Alga, Growth inhibition Test) Update draft, OECD, Paris, France.

OECD (July 2002). Test Guideline 201 (Freshwater Alga and Cyanobacteria, Growth inhibition Test) Update draft, OECD, Paris, France.

Okamura, H.; Mingyu, P.; Aoyama, I.; Sudo, M.; Okubo, T. and Nakamura, M. (2002). Algal growth inhibition by river water pollutants in the agricultural area around lake Biwa, Japan. Environ. Pollut., 117: 411419.

Patterson, M. (2004). Analysis of Risks to Endangered and Threatened Salmon and Steelhead. Environmental Fate and Effects Division; EFED- EPA, Office of Pesticide Programs, Washington, D.C. 20460, p. 22 of 117.

Peterson, K.D. R. (2006). Comparing ecological risks of pesticides: The utility of a risk quotient ranking approach across refinements of exposure. Pest. Manag. Sci., 62:46-56.

Peterson, K.D.R. and Hulting, A.G. (2004). A comparative ecological risk assessment for herbicides used on spring wheat: the effect of glyphosate when used within a glyphosate-tolerant wheat system. Weed Sci., 52: 834-844.

Tisler, T. and Erzen, N.K. (2006). Abamectin in the aquatic environment. Ecotoxicol., 15, 495-502.

US EPA (1994). 96-hour Static Toxicity Test Using Selenastrum capricornutum. SOP\#: 2027. Environmental Protection Agency, Washington.

US EPA (2002 updated). Green alga; Selenastrum capricornutum, Growth Test Method 1003.0. Environmental Research Laboratory, U.S.EPA, Corvallis, OR 97333, pp 197.

US EPA (2005). Ecological Risk Assessment for the Use of Flusilazole to Control Asian Soybean Rust. EPA/128835/D324126/2005. Office of Prevention, Pesticides and Toxic Substances, Washington, DC., 20460. 
Vieira, B.H. (2010). Efeitos do agrotoxico Vertimec_no fitoplancton: um estudo laboratorial and "in situ". MSc Thesis. Escola de Engenharia de Sao Carlos, Universidade de Sao Paulo, Sao Carlos, Brazil.

Wislocki, P.G; Grosso, L.S and Dybas, R.A. (1989). Environmental aspects of abamectin use in crop protection. In: Campbell, W.C. (Ed.), Ivermectin and Abamectin. Springer Verlag, New York, pp. 182-200.

مقارنـة المخـاطر البيئية للمبيدات على طلب الميـاه العذبـة الأخضر وحيد الخليـة Pseudokirchneriella subcapitata

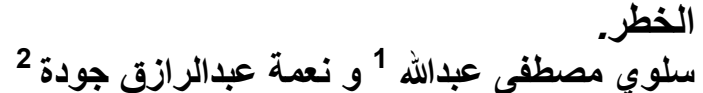

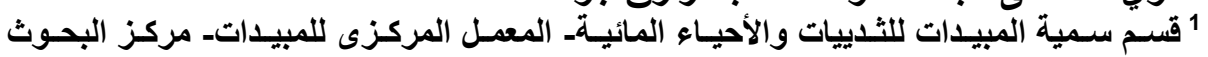

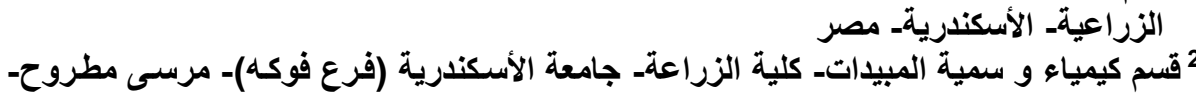
مصر.

تستخدم عمليات تقييم الخطر البيئى غالبا طريقة محصلة الخطر (RQ) لوصف الخطر كميا. وقد تم تقدير

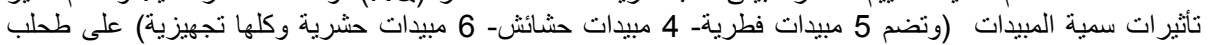

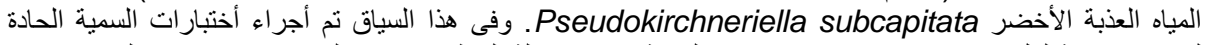

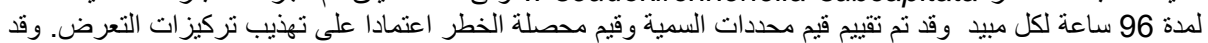

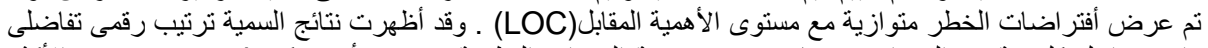

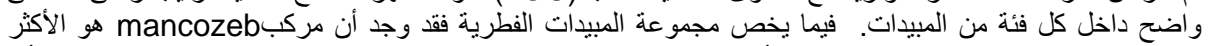

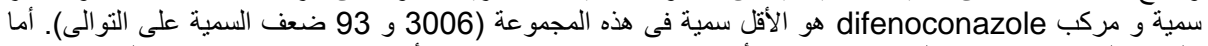

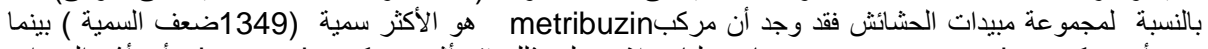

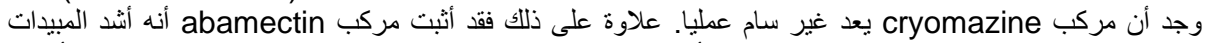

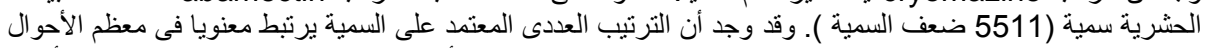

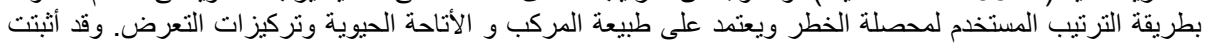
أفتر اضات الخطر المصاحبة ان مركبات mancozeb

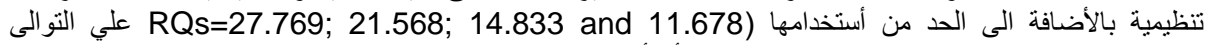

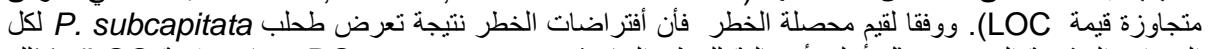

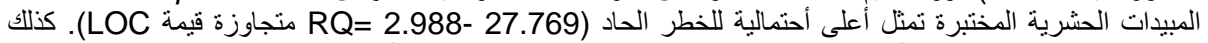

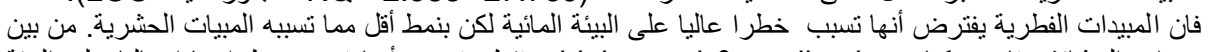

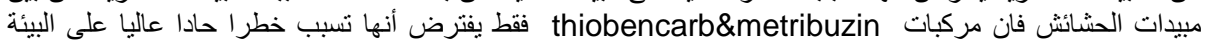

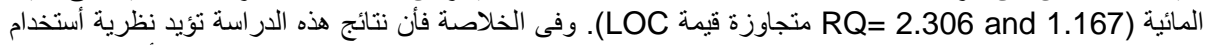

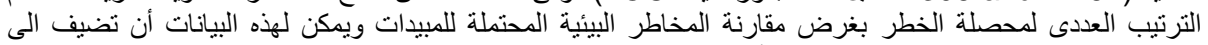
قاعدة البيانات الحالية للمبيدات فيما يتعلق بالتأثير ات السلبية للمبيدات على لفئ البيئة المائية.

كلية الزراعة - جامعة المنصورة كلية الزراعة - جامعة الأسكندريه

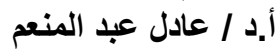

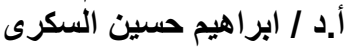

